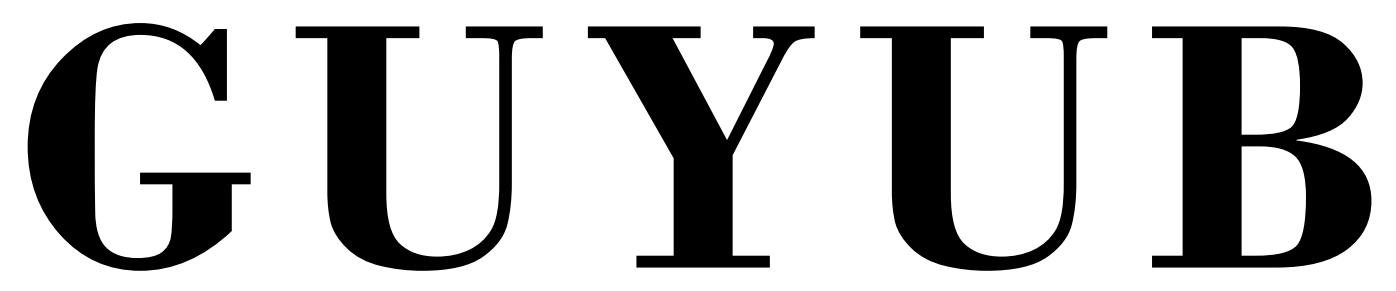

Journal of Community Engagement

Vol. 1, No. 3, Desember 2020

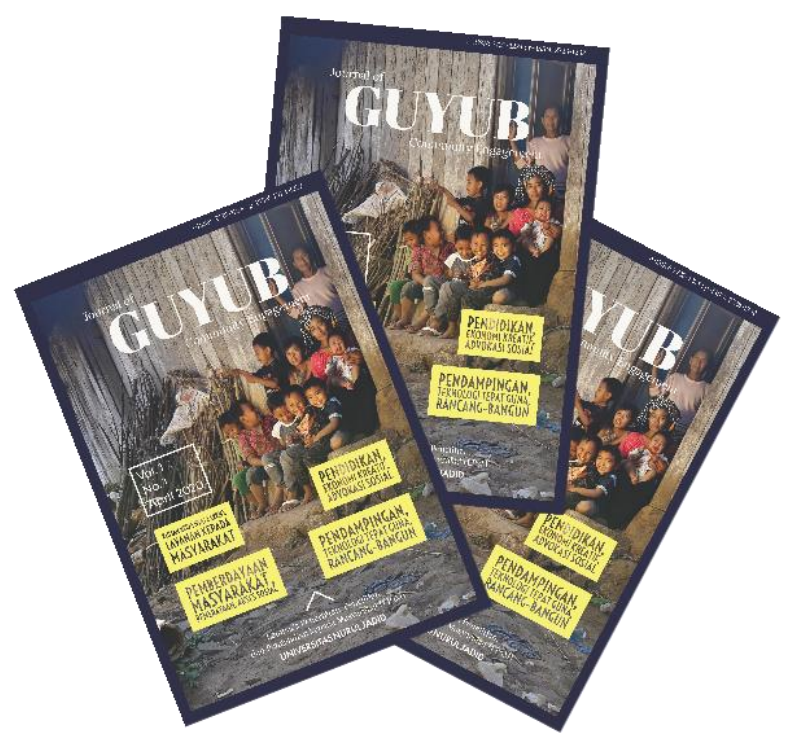

Mengembangkan Kecerdasan Majemuk pada Generasi Milenial Siswa Sekolah Dasar Islam Terpadu (SDIT) Insantama Malang

Retno Sulistiyaningsih ${ }^{1}$, Nur Eva ${ }^{2}$, Nur Rohmah Hidayatul Qoyyimah ${ }^{3}$, Najway Azka Ar-Robbaniy ${ }^{4}$, Sri Andayani ${ }^{5}$

Pendampingan Komunitas Lembaga Pendidikan Bahasa Arab dalam

Pembelajaran Al-Mufradat melalui Media Flash Card di Lembaga Pendidikan Bahasa Arab (LPBA) Al-Qodiri Jember

Muhammad 'Ainul Yaqin', Muhammad Yunus², Muhammad Risqi ${ }^{3}$

Pendampingan Manajemen Resiko Petugas Panitia Pemungutan Suara (PPS) dan Kelompok Penyelenggara Pemungutan Suara (KPPS) Desa Bendosari, Kecamatan Kras, Kabupaten Kediri

Ali Syahidin Mubarok 


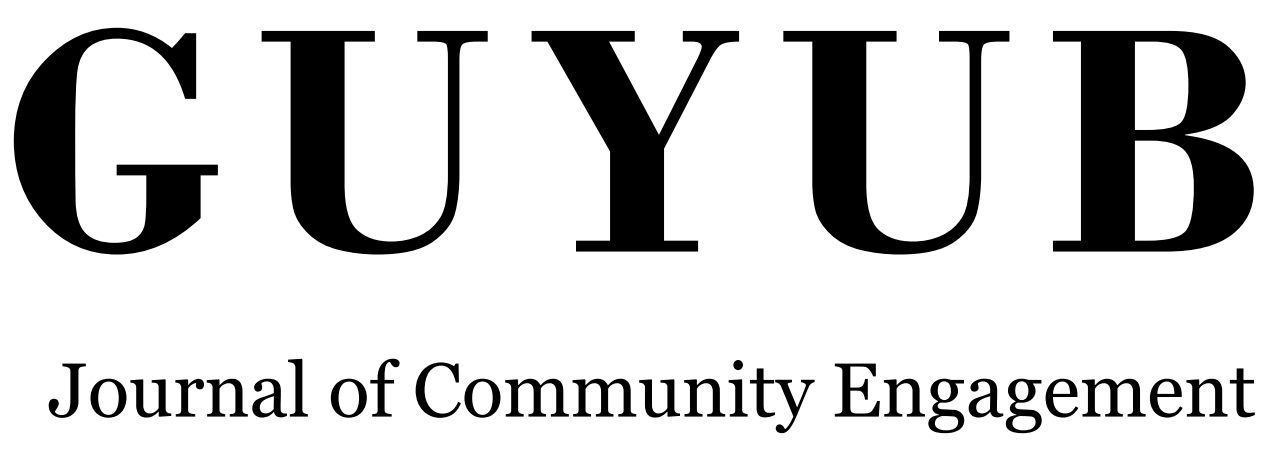




\section{G U Y U B}

\section{Journal of Community Engagement}

Vol. 1, No. 3, 2020

\section{Editor in Chief}

Achmad Fawaid, (SCOPUS ID: 57214837323)

\section{Managing Editors}

Hasan Baharun, (ID SCOPUS : 57200983602)

Sugiono Sugiono, (SCOPUS ID : 57199578160$)$

Ismail Marzuki, (SCOPUS ID: 57201500245

Subhan Rachman, (SCOPUS ID: 57192937912)

Nurul Huda, (SINTA ID: 6119615)

Syamsuri, (SINTA ID: 6116825)

Ridhatullah Assya'bani, (SINTA ID: 6200862)

\section{Peer Reviewers}

Sukamto Sukamto, (SINTA ID: 5979034), Universitas Widya Gama Malang, Indonesia Deny Utomo, (SINTA ID: 6016108), Universitas Yudharta Pasuruan, Indonesia Miftahul Huda, (SINTA ID: 6171566), UIN Maulana Malik Ibrahim Malang, Indonesia Fariz Alnizar, (SCOPUS ID: 6659824), UNUSIA Jakarta, Indonesia Fuad Rahman, (SCOPUS ID: 57201474778), UIN Sulthan Thaha Saifuddin Jambi, Indonesia Saifuddin Zuhri Qudsy, (SCOPUS ID: 57213595165), UIN Sunan Kalijaga Yogyakarta, Indonesia Akhmad Anwar Dani, (SINTA ID: 14305), IAIN Surakarta, Indonesia Maufur Maufur, (SINTA ID: 5989329), IAIN Kediri, Indonesia Siti Mahmudah Noorhayati, (SINTA ID: 6726997), IAIN La Roiba Bogor, Indonesia Busro Busro, (SCOPUS ID: 57205022652), UIN Sunan Gunung Djati Bandung, Indonesia Akmal Mundiri, (SCOPUS ID: 57205059378), UNUJA Probolinggo, Indonesia

\section{Section Editor}

Ahmad Zubaidi, Universitas Nurul Jadid, Probolinggo, Indonesia 
GUYUB: Journal of Community Engagement is is a multidisciplinary journal which aims to disseminate the conceptual thoughts and research results in the area of community service. This journal focuses on the main problems of the community engagement areas, such as (1) training, marketing, appropriate technology, design; (2) student community services; (3) community empowerment, social access; (4) education for sustainable development, etc.

GUYUB: Journal of Community Engagement is published three times a year (April, August, December) by Lembaga Penerbitan, Penelitian, dan Pengabdian kepada Masyarakat (LP3M) Universitas Nurul Jadid, Paiton, Probolinggo, Jawa Timur, Indonesia.

Editorial Office:

GUYUB: Journal of Community Engagement

Lembaga Penerbitan, Penelitian, dan Pengabdian kepada Masyarakat (LP3M) Universitas Nurul Jadid, Paiton, Probolinggo, Jawa Timur, Indonesia 67291.

Phone: 088830 77077, Hp: 082318007953

Email: jurnal.guyub@gmail.com

Website: https://ejournal.unuja.ac.id/index.php/guyub/index 


\section{Tables of Content}

157-166

Mengembangkan Kecerdasan Majemuk pada Generasi Milenial Siswa Sekolah Dasar Islam Terpadu (SDIT) Insantama Malang

Retno Sulistiyaningsih, Nur Eva, Nur Rohmah Hidayatul Qoyyimah, Najway Azka Ar-Robbaniy, Sri Andayani

167-178

Pendampingan Komunitas Lembaga Pendidikan Bahasa Arab dalam Pembelajaran Al-Mufradat melalui Media Flash Card di Lembaga Pendidikan Bahasa Arab (LPBA) Al-Qodiri Jember Muhammad 'Ainul Yaqin, Muhammad Yunus, Muhammad Risqi

$179-190$

Pendampingan Manajemen Resiko Petugas Panitia Pemungutan Suara (PPS) dan Kelompok Penyelenggara Pemungutan Suara (KPPS) Desa Bendosari, Kecamatan Kras, Kabupaten Kediri Ali Syahidin Mubarok

$191-203$

KKM Refungsionalisasi Masjid: Optimalisasi Fungsi dan Peran Masjid Al-Ikhlas Dusun Glundengan Desa Suci Kecamatan Panti Kabupaten Jember

Finadatul Wahidah, Abdul Sholeh, Putri Nur Hayati

204-214

Pengembangan Sistem Informasi Monitoring Program Kerja Berbasis Android pada Fakultas Teknik Universitas Nurul Jadid

Fathorazi Nur Fajri, Kamil Malik, Halimatus Sa'diya

215-226

Perancangan Sistem Monitoring Surat Perintah Perjalanan Dinas dengan Mobile App Android untuk Biro Kepegawaian Universitas Nurul Jadid

Fathorazi Nur Fajri, M. Noer Fadli Hidayat, Suci Rahayu Agustini

227-237

Pengembangan Sistem Online Pendaftaran Santri Baru untuk Penguatan Manajemen Informasi Pondok Pesantren Islamiyah Syafi'iyah Situbondo

Fathorazi Nur Fajri, Wali Ja'far Shudiq, Nurul Hidayattun Nasyihin 


\title{
KKM Refungsionalisasi Masjid: Optimalisasi Fungsi dan Peran Masjid Al-Ikhlas Dusun Glundengan Desa Suci Kecamatan Panti Kabupaten Jember
}

\author{
Finadatul Wahidah ${ }^{1}$, Abdul Sholeh², Putri Nur Hayati ${ }^{3}$
}

Institut Agama Islam Al-Qodiri Jember, Indonesia 1,2,3

\{ fynadatulwahidah@gmail.com ${ }^{1}$, putrinurhayati.alqodiri@gmail.com ${ }^{1,3}$ \}

Submitted: 13 September $2020 \quad$ Received: 10 Oktober $2020 \quad$ Published: Desember 2020

Keywords: $\quad$ Abstract. This community service is to optimize the position and function of the mosque as not merely a location for worship rituals, but also a place of education, such as

Mosque, Role, religious education (Madrasah Diniyah), tutoring (Bimbingan Belajar), Al-Quran Function education park (Taman Pendidikan Al-Quran). Since some of the Suci people at the Glundengan village are very busy with work and other activities, they have lack of attention on their religious affairs. By announcing the five prayer at the Al-Ikhlash Mosque, this community service which is based on PAR (Participatory Action Research) approach as a methodological approach is to arouse the community's enthusiasm to pray in the Mosque, and we provide an example to enliven the congregation at the mosque. The most of Glundengan people have lower educational level, which can be seen from the lack of undergraduate graduates, and this situation has caused any migration to town. The program of 'refunctionalizing' mosque is important, since there is also Christian religious worship in Glundengan, a church located in RT 2, which is not far from the mosque. The PAR (Participatory Action Research) approach is the methodology used.

Kata kunci: $\quad$ Abstrak. Tujuan dari pengabdian masyarakat ini adalah untuk mengoptimalkan peran dan fungsi masjid yang tidak hanya difungsikan sebagai tempat ritual peribadatan saja, Masjid, Peran, melainkan juga sebagai tempat pendidikan misalkan pendidikan madrasah diniyah, Fungsi bimbingan belajar, TPQ. Mengingat bahwa sebagaian masyarakat Desa Suci, khususnya Dusun Glundengan, sangat sibuk dengan pekerjaan dan aktivitas lain, sehingga untuk urusan beribadah mereka dirasa kurang. Dengan menggunakan metode Participatory Action Research (PAR), pendampingan ini fokus untuk refungsionalisasi masjid dalam aspek peribadatan dan pendidikan, antara lain dengan mengumandangkan adzan 5 waktu shalat di Masjid Al-Ikhlash, yang bertujuan untuk membangkitkan semangat masyarakat untuk berbondong-bondong shalat berjamaah, melaksanakan bimbel, Madin, dan TPQ. Masyarakat Glundengan memiliki tingkat pendidikan rendah, hal ini dilihat dari lulusan sarjana minim sehingga menyebabkan banyaknya remaja yang merantau ke luar kota. Refungsuionalisasi masjid di Dusun Glundengan ini dirasa sangat perlu untuk dilakukan, mengingat juga bahwa di Dusun Glundengan juga terdapat tempat beribadah agama Kristen, yakni Gereja yang berada di RT 2 lokasinya tidak jauh dari masjid. 


\section{PENDAHULUAN}

Hakikat masjid menurut Moh E Ayyub (1996: 7) adalah tempat melakukan segala macam aktivitas yang mengandung kepatuhan kepada Allah Swt. Dengan kata lain, masjid berarti suatu tempat melakukan segala aktivitas yang mencerminkan nilai-nilai kepatuhan dan ketaatan kepada Allah. Masjid sebagai lembaga keagamaan merupakan tempat perjumpaan dan berkumpulnya umat secara rutin dengan hati dan pikiran yang jernih. Fungsi utama masjid adalah tempat sujud kepada Allah SWT, tempat shalat, dan tempat beribadah kepadaNya. Lima kali sehari semalam umat Islam dianjurkan mengunjungi masjid guna melaksanakan shalat berjama'ah. Selain itu fungsi masjid adalah sebagai tempat bermusyawarah kaum muslimin guna untuk memecahkan persoalan-persoalan yang timbul dalam masyarakat (Wiyani, 2013).

Quraish Shihab (1996: 459) berpendapat bahwa masjid dalam pengertiannya adalah tempat shalat umat Islam, namun akar katanya terkandung makna 'tunduk' dan 'patuh'. Maka dari itu masjid pada hakikatnya adalah tempat melakukan segala aktivitas apa saja yang mengandung ketundukan kepada Sang Pencipta. Pada masa Rasulullah SAW, fungsi masjid tidak hanya sebagai tempat shalat saja, namun juga menjadi sentral utama seluruh kegiatan keummatan, yakni sentral pendidikan, politik, ekonomi, sosial dan budaya (Syamsul Kurniawan, 2014: 176) . Suyudi (2005: 225-226) menjelaskan bahwa fungsi masjid pada masa Rasulullah Saw adalah sebagai tempat berkumpulnya umat Islam, yang tidak terbatas pada waktu shalat saja, melainkan juga digunakan untuk menunggu informasi turunnya wahyu.

Namun, dewasa ini, fungsi masjid hanya sebatas tempat ibadah saja, berbeda dengan fungsi masjid pada masa Rasulullah. Pada masa Rasulullah SAW fungsi masjid selain tempat beribadah yakni juga berfungsi sebagai tempat pendidikan, informasi, kesehatan, ekonomi, bahkan juga digunakan untuk mengatur negara dan strategi perang (Nurjamilah, 2017).

Dusun Glundengan adalah dusun yang terbanyak penduduknya dibanding dengan dusun lainnya yang berada di Desa Suci., terbagi 5 RW dan 30 RT, dengan jumlah kurang lebih 1.250 KK, 7.000 jiwa. Mayoritas penduduk Dusun Glundengan ini adalah petani, buruh, dan imigrasi. Dari hasil observasi di daerah Dusun Glundengan, Desa Suci Panti Jember, banyaknya kuantitas masyarakat di dalam dusun tersebut menjadikan 
perekonomian dan pembangunannya lebih baik dari pada dusun-dusun yang lainnya.

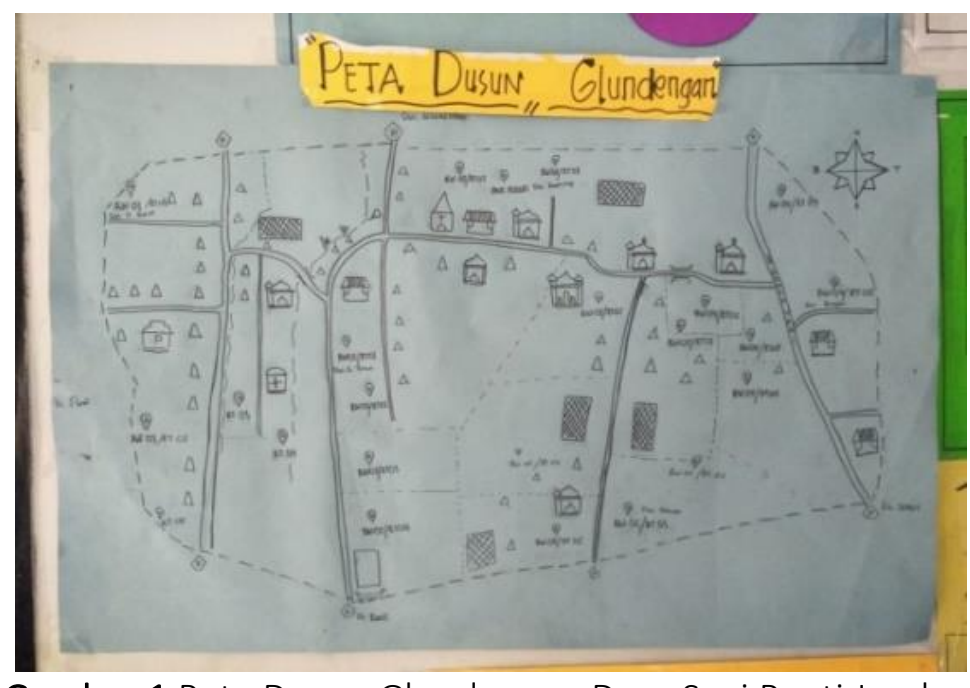

Gambar 1 Peta Dusun Glundengan Desa Suci Panti Jember

Sebagaimana pada umumnya masyarakat pedesaan, masyarakat Desa Suci, khususnya Dusun Glundengan, sangat sibuk dengan pekerjaan tani sehari-hari mereka, sehingga urusan beribadah mereka dirasa kurang. Maka dari itu, program pengabdian ini difokuskan untuk meramaikan jamaah di masjid, dengan mengumandangkan adzan 5 waktu shalat di Masjid Al-Ikhlash, yang bertujuan untuk membangkitkan semangat masyarakat untuk berbondong-bondong shalat berjamaah yang dimulai dari peserta Kuliah Kerja Mahasiswa (KKM) IAI Al-Qodiri. Masyarakat Glundengan memiliki tingkat pendidikan rendah. Hal ini dilihat dari lulusan sarjana yang relatif minim, sehingga menyebabkan banyaknya remaja yang merantau ke luar kota.

Refungsionalisasi masjid di Dusun Glundengan ini dirasa sangat perlu untuk dilakukan, mengingat juga bahwa di dusun Glundengan juga terdapat tempat beribadah agama Kristen, yakni gereja yang berada di RT 2 tidak jauh dari masjid. Masjid Al-Ikhlas memang bukan satu-satunya masjid yang ada di dusun Glundengan. Namun dari beberapa masjid yang ada di dusun Glundengan, masjid Al-Ikhlas merupakan satu-satunya masjid yang melaksanakan pendidikan Diniyah bagi masyarakat dusun Glundengan dengan santri dari sekolah pendidikan PAUD hingga sekolah Dasar. 


\section{METODE}

Dalam melakukan pengabdian pada masyarakat ini, metode yang digunakan adalah PAR (Participatory Action Research). Metode ini dilakukan untuk memberikan pemahaman masyarakat terhadap: a) Kelemahankelemahan yang dimiliki; b) Keinginan masyarakat untuk mengatasi kekurangan dan kelemahan; c) Menyusun strategi dan metode untuk memecahkan masalah; d) Membantu masyarakat mengatasi, memecahkan, dan menemukan solusi dari permasalahan. (Ghozali \& Haqq, 2018)

Metode PAR ini digunakan untuk tidak membuat masyarakat dampingan sebagai obyek, tetapi menjadikannya sebagai subyek penelitian. Masyarakat sendiri yang memahami, menginginkan, dan memecahkan permasalahan dihadapi. Posisi peneliti sebagai fasilitator bagi masyarakat untuk mencapai keinginan masyarakat dan memberikan jalan keluar dengan merumuskan strategi yang dapat digunakan masyarakat untuk mengatasi permasalahan tersebut. Perumusan strategi ini tetap melibatkan masyarakat dengan harapan apabila masyarakat mengalami masalah sosial, mereka bisa memecahkan permasalahan mereka sendiri tanpa bantuan orang lain. (P3M STAI Al-Qodiri Jember, 2019)

Adapun langkah-langkah yang digunakan dalam kegiatan pengabdian kepada masyarakat sebagaimana berikut (Husni, 2017):

Pertama, Perencanaan. Dalam tahap ini rencana dibuat setelah memperhatikan kondisi riil masyarakat. Dalam tahap perencanaan ini menggunakan Participatory Assement dan Participatory Planning, menganalisis problematika di masyarakat dan menganalisis kekuatan, kelemahan, peluang, dan ancaman yang terjadi di masyarakat ini dilakukan dengan melibatkan masyarakat di dusun Glundengan. Perencanaan ini meliputi strategi dan metode dalam memecahkan problematika kebahasaan yang dihadapi oleh masyarakat.

Kedua, Tindakan. Setelah proses perencanaan dilakukan, masyarakat Glundengan mengimplementasikan rencana yang telah dibuat dengan difasilitasi oleh peneliti. Bentuk kegiatan yang akan dilakukan dalam penelitian action research ini terdiri dari dari Keagamaan dan pendidikan. Seluruh proses dan siklus kegiatan dilakukan oleh subyek pengabdian dan peneliti, diobservasi, dimonitoring dan dievaluasi. 
Ketiga, Observasi. Pengamatan dilakukan untuk memperhatikan dan menganalisis keberhasilan, kelemahan, dan kekurangan strategi dan metode yang digunakan dalam menyelesaikan problematika yang terjadi di masyarakat Glundengan.

Keempat, Refleksi. Usaha yang telah dilakukan dalam memecahkan problematika di masyarakat Glundengan tersebut direfleksikan dan dievaluasi, baik kekurangan, kelemahan, dan keberhasilan strategi dan metode dalam memecahkan problematika keagamaan dan pendidikan masyarakat tersebut.

\section{DISKUSI DAN PEMBAHASAN}

\section{Pelaksanaan Program Pengabdian}

Sebagian masyarakat Dusun Glundengan sangat sibuk dengan pekerjaan dan aktivitas lain, sehingga untuk urusan beribadah mereka dirasa kurang. Maka dari itu kami memberikan contoh untuk meramaikan berjamaah di masjid, dengan mengumandangkan adzan 5 waktu shalat di Masjid Al-lkhlash, yang bertujuan untuk membangkitkan semangat masyarakat untuk berbondong- bondong shalat berjamaah yang dimulai dari peserta KKM IAI Al- Qodiri.

Masyarakat Glundengan memiliki tingkat pendidikan rendah. Hal ini dilihat dari tingkat lulusan sarjana yang minim sehingga menyebabkan banyaknya remaja yang merantau ke luar kota bahkan sebagian dari mereka banyak menjadi pengangguran. Oleh karena itu, kami KKM IAI Al-Qodiri mendirikan program yang disebut "Refungsionalisasi Masjid" dalam membantu meningkatkan tingkat religiusitas dan pendidikan di Dusun Glundengan Desa Suci.

Pelaksanaan program fungsionalisasi masjid ini dilakukan dalam dua bidang yang menjadi prioritas utamanya, yakni bidang keagamaan dan bidang pendidikan.

a. Keagamaan

Program keagamaan yang dilakukan adalah masyarakat gemar jama'ah. Masyarakat gemar jama'ah dilaksanakan guna untuk mengaktifkan kegiatan keagamaan seperti halnya jamaah ataupun pengajian. Di dalam program masyarakat gemar jamaah ini kami melaksanakannya yaitu lebih mengaktifkannya dalam ranah shalat berjamaah lima waktu. 
Program masyarakat gemar jamaah ini diadakan dengan diawali pembersihan tempat, baik dari lantai masjid hingga pembersihan prasarana jeding/wc, kemudian dilanjutkan peletakan karpet dan sajadah-sajadah.

Program ini dilaksanakan oleh para peserta KKM IAI Al-Qodiri Jember sebagai awal dalam rangka mengajak warga sekitar untuk ikut berjamaah di masjid tersebut. Dalam ini kami sambil lalu bersilaturrahmi ke warga-warga sekitar dengan cara memaparkan mengenai keberadaan dari suatu masjid yang awalnya sudah kurang aktif atau tidak adanya kegiatan bahwasanya sudah dijadikan program dari para peserta KKM IAI Al-Qodiri Jember untuk diaktifkannya shalat berjamaah salah satunya. Dengan hal itu sedikit banyak para warga ikut juga dalam shalat berjamaah di masjid tersebut.

b. Pendidikan

1) Pembinaan Madrasah Diniyah (Madin)

Program pembinaan Madin dilaksanakan setiap hari kecuali hari Jum'at libur pada Jam 15.00 sampai dengan Jam 17.30 WIB di Masjid AlIkhlash. Adapun di dalam pelaksanaan program pembinanaan Madin ini telah mendapatkan suatu restu dari pihak kepala madin kepada para peserta KKM IAI Al-Qodiri Jember untuk pembuatan absen dan segala administrasi yang dilaksanakan oleh pihak kami seluruhnya. Dalam program pembinaan Madin ini, antara lain yakni membentuk kepengurusan madin, jadwal pelajaran beserta asatidz yang akan menagajar di Madrasah Diniyah Dusun Glundengan Desa Suci Panti Jember, dan penetapan murid Madarasah Diniyah yang terbagi menjadi empat tingkatan yaitu paud, TK, kelas I dan kelas II.

Guna memaksimalkan program pembinaan Madin ini dibentuk juga absensi kehadiran murid Madin yang bertujuan untuk memaksimalkan kehadiran santri. Sementara itu, untuk materi pelajaran di kelas PAUD lebih difokuskan pada pembelajaran membaca Al-Qur'an dengan metode Tilawati dan dibantu dengan alat peraga. Untuk tingkat TK, materi pembelajarannya mulai dari do'a sehari-hari, do'a shalat, dan praktik shalat.

Materi pelajaran di tingkat kelas I difokuskan pada pelajaran Tajwid, Bahasa Arab, Bahasa Inggris, dan Fiqih. Materi pelajaran untuk kelas II yakni pelajaran Tajwid, Akhlaq, Bahasa Arab, Bahasa Inggris dan Fiqih dengan tingkatan kitab yang lebih tinggi. Mengenai teknis pembagian kelas antara PAUD dan TK dibagi denga mekanisme 
tertentu. Untuk kelas I dan II pembagian kelasnya melihat pada aspek pengetahuan agama yang dimiliki santri melalui tes.

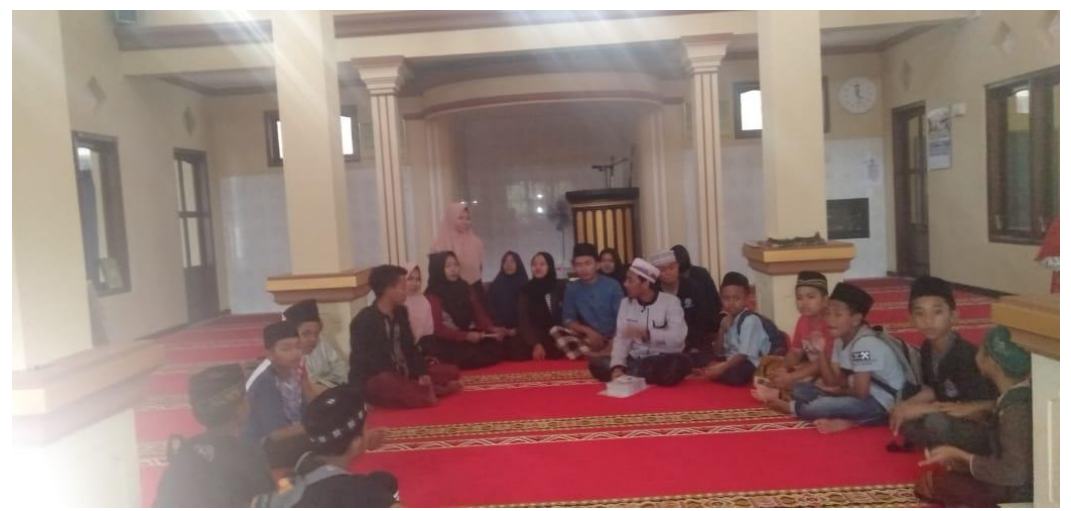

Gambar 2. Musyawarah dengan Pengurus Madin

2) Pembinaan Taman Pendidikan Al-Quran (TPQ)

Program pembinaan TPQ dilaksanakan setiap malam, kecuali untuk malam Jum'at dan malam Selasa diganti praktik shalat. Dilaksanakan ba'da shalat jamaah Magrib sampai Isya'. Adapun mengenai program TPQ ini sebenarnya sudah ada sebelum adanya KKM IAI Al-Qodiri Jember.

Program ini berisi tentang cara mengajar dan cara membaca AlQur'an yang baik dan benar sesuai tajwid dan makharijul huruf. Strategi pengajarannya adalah memperhatikan satu demi satu santri ketika membaca Al-Qur'an kemudian meluruskannya ataupun membenarkannya, selain juga strategi pengajaran lain, seperti membaca Al-Qur'an dari ayat ke ayat kemudian diikuti oleh santri.

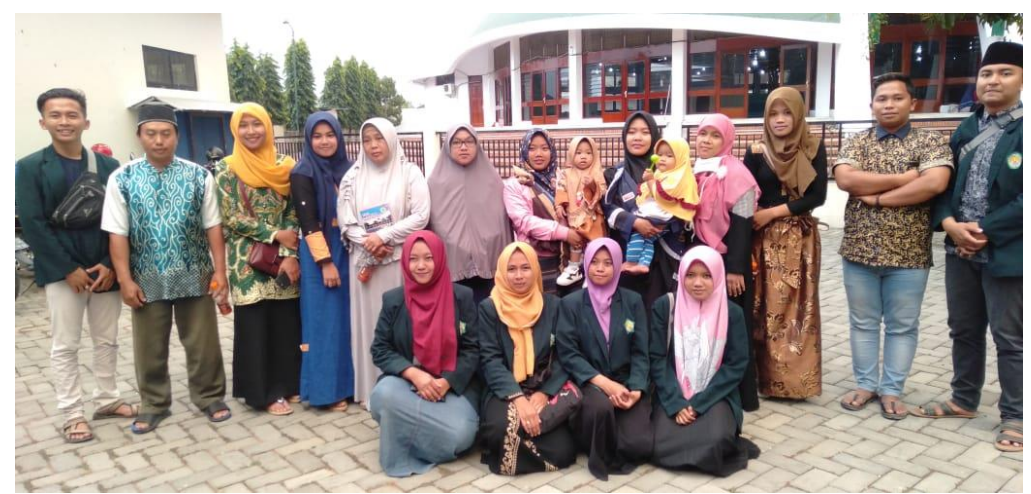

Gambar 3. Studi Banding dengan TPQ Al-Baitul Amin Jember 
3) Pelaksanaan Bimbingan Belajar (Bimbel)

Program ini dilaksanakan setiap malam, kecuali malam Jum'at dan malam Minggu libur. Dilaksanakan pukul 19.00 sampai dengan pukul 20.30 atau paling akhir pukul 21.00. Dalam program bimbingan belajar ini diikuti kurang lebih 20 peserta didik yang terdiri dari lembaga SD mulai dari kelas 1 hingga kelas 6 dan SMP kelas 1 dan II. Program ini dilaksanakan untuk memberdayakan anak-anak setempat yang tidak memiliki kesibukan setelah Isya' juga guna untuk menambah semangat belajar. Pelaksanaan bimbingan belajar ini relatif berhasil karena banyak anak-anak setempat mengikuti kegiatan ini dan semangat dalam belajar.

\section{4) Pemutaran Film Motivasi Semangat Belajar}

Program pemutaran film motivasi semangat belajar ini dilaksanakan pada Hari Kamis, 07 Agustus 2018 Jam 15:30 sampai dengan Jam 16:30 di Madrasah Diniyah Al-Ikhlas. Yang mana dalam program ini, dikemas menjadi suatu acara ceremonial yang diikuti oleh santri kelas TK, Kelas I dan II Diniyyah. Dalam program ini pemaparan yang disampaikan ketua posko lebih mentitikberatkan bagaimana begitu pentingnya pendidikan terutama dalam semangat mewujudkan impian atau cita-cita. Judul film yang diputar "Cita-citaku Setinggi Tanah". Dalam pelaksanaannya banyak hal yang menjadi suatu kebanggaan dari Kepala Madrasah Diniyah sebab meningkatnya motivasi belajar dan semangat murid diniyah dalam meraih cita-cita.

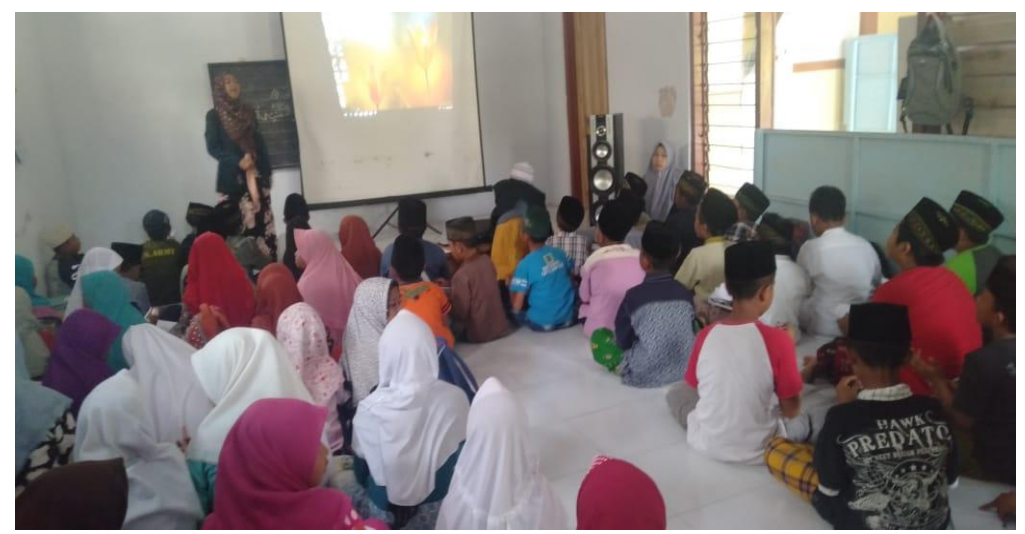

Gambar 4. Acara Pemutaran Film Motivasi Semangat Belajar 


\section{5) Pendirian Rumah Baca}

Program ini dibentuk untuk membangun semangat anak-anak dan remaja di Dusun Glundengan untuk membaca, karena di era milenial ini anak-anak dan remaja lebih memilih gadget daripada membaca buku. Yang mana gadget lebih banyak digunakan untuk hiburan dari pada belajar ilmu pengetahuan dan itu membuat mereka semakin malas belajar. Oleh karena itu KKM IAI Al-Qodiri Jember berinisiatif untuk mendirikan rumah baca yang dapat membantu untuk membangun semangat belajar anak-anak dan remaja. Rumah baca ini didirikan di Dusun Glundengan yang bertempat di Masjid Al-Ikhlas.

Untuk pengumpulan buku, peserta KKM IAI Al-Qodiri Jember mencari dana dengan menyebarkan proposal ke para donator dan juga masyarakat dan sebagian juga ada yang mendonasikan bukunya. Selain itu peserta KKM IAI Al-Qodiri Jember menerima donasi dari media sosial.

Buku yang terkumpul mencapai kurang lebih 400 buku yang terdiri dari kitab fikih, buku dongeng, buku tilawati, buku bimbingan shalat, dan kamus. Untuk mendirikan rumah baca tersebut KKM IAI AlQodiri Jember meminta perizinan dari pihak remas dan kepala diniyah.

\section{6) Pendirian Rumah Baca}

Kegiatan ini dilaksanakan untuk meresmikan rumah baca sekaligus pelantikan pengurus rumah baca. Yang mana tujuan dari peresmian rumah baca tersebut untuk pengenalan kepada tokoh masyarakat beserta murid madrasah diniyah. Kegiatan ini dilaksanakan pada tanggal 25 agustus 2019 yang mana dimulai pada jam 15.0017.00 .

Kegiatan ini dibuka dengan permainan menjawab pertanyaan dari panitia dan bagi yang menjawab pertama dan jawabannya benar maka dia berhak mendapat hadiah bagi TK dan PAUD dan bagi siswa SD mengikuti perlombaan kolase. Pembukaan tersebut dilaksanakan sambil menunggu shalat Ashar dan menunggu undangan yang belum hadir. Setelah pelaksanaan shalat ashar dilanjutkan dengan ceremonial dan ditutup dengan pemotongan pita dan pelepasan balon. Acara launching tersebut mendapat suatu apresiasi dari kepala madrasah diniyyah 
karena tidak terfikirkan oleh masyarakat dusun Glundengan akan terbentuknya rumah baca.

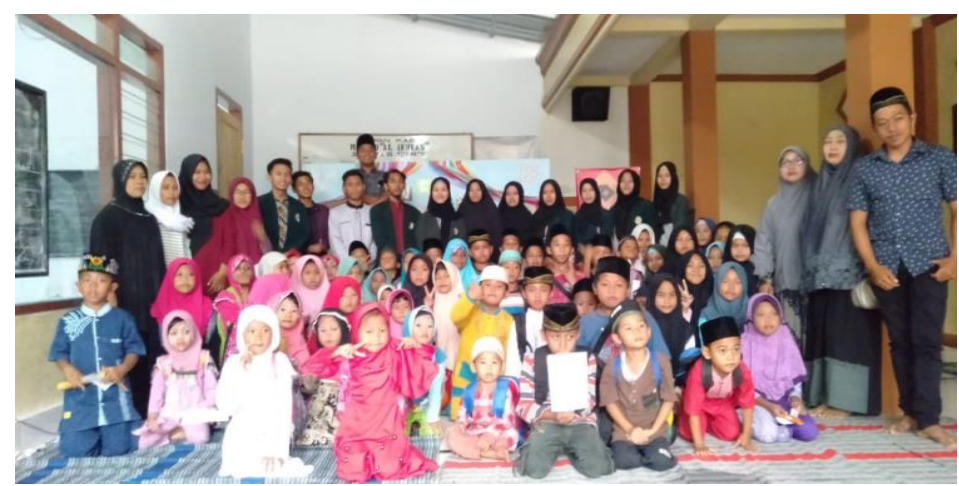

Gambar 5. Launching Rumah Baca

\section{Evaluasi Program}

a. Keagamaan

Dalam program yang kami laksanakan yaitu mengenai masyarakat gemar jama'ah terdapat banyak kendala Dan juga dalam program ini para jama'ah yang berasal dari para warga tidak begitu banyak dan tidak bertahan lama dikarenakan adanya kesibukan pekerjaan. Terkadang dalam pelaksanaan program masyarakat gemar jama'ah ini para peserta KKM IAI Al-Qodiri Jember merasa kerepotan karena juga banyak program pada jam yang sama dengan hal itu kami membagi tugas.

b. Pendidikan

1) Pembinaan Madrasah Diniyah (Madin)

Dalam program ini kami sudah begitu maksimal dalam pelaksanaannya dikrenakan sudah terbentuk suatu sistem dalam pembelajaran baik dari sudah terbentuknya jadwal pelajaran dan jadwal pengajar. Adapun kendalanya adalah ketidakleluasaan di saat mengajar karena dipantau oleh guru-guru yang mengajar pada jam tersebut. Kendalanya juga adalah masih minimnya ruang kelas dan juga minimnya prasarana pembelajaran. Akan tetapi program pembinaan Madin sudah berjalan dengan baik dan lancar.

2) Pembinaan Taman Pendidikan Al-Quran (TPQ)

Dalam program ini tidak banyak kendala ataupun tidak banyak evaluasi dikarenakan kendalanya hampir sama dengan program pembinaan Madin, yakni adanya program yang berbenturan dengan 
kegiatan kemasyarakatan, sehingga membuat tidak maksimalnya program pembinaan TPQ ini.

3) Pelaksanaan Bimbingan Belajar (Bimbel)

Program ini berjalan dengan baik, dikarenakan juga banyaknya peserta les, juga dikarenakan adanya semangat dari anak-anak Dusun Glundengan Desa Suci Panti Jember untuk belajar. Akan tetapi, banyak peserta les yang rumahnya jauh meskipun tidak berdampak pada semangat belajar les mereka.

Pelaksanaan Bimbel ini mendapat apresiasi dari warga sekitar, selain warga merasa dibantu ananknya, juga dikarenakan dusun mereka ramai dan terasa hidup. Akan tetapi, kendala yang kami rasakan di saat memasuki Bulan Agustus adalah banyaknya anak-anak yang mengikuti perlombaan, sehingga semakin sedikit yang mengikuti program Bimbingan Belajar.

4) Pemutaran Film Motivasi Semangat Belajar

Evaluasi mengenai program ini memiliki suatu dampak positif dan apresiasi dari pihak Madrasah Diniyyah. Dalam hal ini ada ada beberapa kendala diantaranya ruangan ramai dikarenakan waktu Madrasah Diniyah sudah selesai.

Dalam pemutaran film motivasi semangat belajar kami meminta izin kepala diniyyah untuk meminta jam pada hari tersebut dan kepala sekolah dengan senang hati mengizinkan kami. Dan kami mendapatkan apresiasi dari kepala sekolah dan guru-guru Madrasah Diniyyah.

5) Pendirian Rumah Baca

Dalam program ini yang mengalami kendala adalah kurang banyaknya fasilitas buku di rumah baca.

\section{Rencana Tindak Lanjut}

Dengan terealisasinya program KKM IAI Al-Qodiri Jember tentunya tidak hanya berhenti sebatas menciptakan suatu program saja, melainkan juga bagaimana mempertahankan program tersebut. Program refungsionalisasi masjid yang KKM IAI Al-Qodiri Jember laksanakan dengan dibarengi sebuah tindak lanjut yakni dengan melakukan beberapa musyawarah. Adapun hasil musyawarahnya yaitu pembentukan Rumah baca ,"Rumah Batja Glundengan". Dari pembentukan struktur kepengurusan tersebut kami mempunyai rencana tindak lanjut agar meneruskan program 
rumah badja di Dusun Glundengan desa Suci yang telah didirikan oleh peserta KKM IAI Al-Qodiri Jember. Adapun rencana tindak lanjutnya adalah sebagai berikut:

1. Penetapan struktur kepengurusan mulai dari pembentukan ketua hingga pembentukan nama-nama yang menjadi bagian pendanaan buku dan pengembangan rumah baca.

2. Dilakukannya suatu penyampaian mengenai tugas, pokok dan fungsi dari masing-masing jabatan di dalam struktur kepengurusan agar tidak ada kerancuan atau kebingungan dalam melaksanakan tugasnya.

3. Diadakannya suatu acara ceremonial peresmian rumah baca yang dihadiri kepala diniyah, asatidz, dan murid-murid Diniyah.

4. Dilakukannya sebuah pengawalan dan pendampingan dari kami kepada kepengurusan rumah baca tersebut guna tetap dalam satu tujuan keinginan bersama dan guna maksimalnya kinerja mereka.

\section{PENUTUP}

Refungsionalisasi masjid di Dusun Glundengan Desa Suci Panti Jember ini diharapkan dapat memberikan manfaat dan dan dapat memberdayakan serta dapat memfungsikan masjid tidak hanya sebatas sebagai tempat shalat saja.

Adapun program program KKM refungsionalisasi masjid ini antara lain. Pertama, Pelaksanaan Madrasah Diniyah (Madin) yang dilaksanakan setiap ba'da shalat Ashar; Kedua, Pembinaan TPQ ini dilaksanakan setelah shalat maghrib sampai dengan shalat Isya'. Untuk mendapatkan pendalaman tentang kepungurusan TPQ, pengurus TPQ beserta peserta KKM di bawah bimbingan DPL melakukan studi banding ke TPQ terbaik di Jember; Ketiga, Pelaksanaan Bimbingan Belajar; Keempat, Pemutaran Film Motivasi Semangat Belajar; dan Kelima, Pendirian Rumah Baca Dusun Glundengan Desa Suci Panti Jember. 


\section{DAFTAR PUSTAKA}

Ayyub, M. E. 1996. Manajemen Masjid. Jakarta: Gema Insani

Ghozali, M., \& Haqq, A. A. (2018). Program Participatory Action Research Melalui Pendekatan Dakwah Bil Hal. ORASI: Jurnal Dakwah dan Komunikasi, 9(2), 115-128.

Husni, M. (2017). Konseling Sebaya dalam Memberdayakan Anak Jalanan Berbasis Masjid (Inkorporasi Perspektif Anak Jalanan Berbasis Komunitas Melalui Pendekatan Participatory Action Research). Panangkaran: Jurnal Penelitian Agama dan Masyarakat, 1(2), 237-256.

Kurniawan, S. 2014. Masjid dalam Sejarah Lintasan Ummat Islam. Journal of Islamic Studies Volume 4 Nomor 2 September

Nurjamilah, C. (2017). Pemberdayaan Masyarakat Berbasis Masjid dalam Perspektif Dakwah Nabi saw. Journal of Islamic Studies and Humanities, 1(1), 93-119.

Pusat Penelitian dan Pengabdian kepada Masyarakat (P3M) STAI Al-Qodiri Jember. 2019. Buku Panduan KKM IAI Al-Qodiri Jember.

Shihab, Quraish. 1996. Wawasan Al-Qur'an. Jakarta: Mizan.

Suyudi, 2005. Pendidikan dalam Perspektif Al-Qur'an: Integrasi Epistemologi Bayani, Burhani, dan Irfani. Yogyakarta: Mikraj

Wiyani, N. A. (2013). Fungsionalisasi Masjid Sebagai Laboratorium Pendidikan Karakter di Sekolah Dasar. Al-Bidayah: Jurnal Pendidikan Dasar Islam, 5(2). 


\section{GUYUB}

\section{Journal of Community Engagement}

P-ISSN: 2723-1232

E-ISSN: 2723-1224

GUYUB: Journal of Community Engagement is is a multidisciplinary journal which aims to disseminate the conceptual thoughts and research results in the area of community service. This journal focuses on the main problems of the community engagement areas, such as (1) training, marketing, appropriate technology, design; (2) student community services; (3) community empowerment, social access; (4) education for sustainable development, etc.

GUYUB: Journal of Community Engagement is published three times a year (April, August, December) by Lembaga Penerbitan, Penelitian, dan Pengabdian kepada Masyarakat (LP3M) Universitas Nurul Jadid, Paiton, Probolinggo, Jawa Timur, Indonesia.
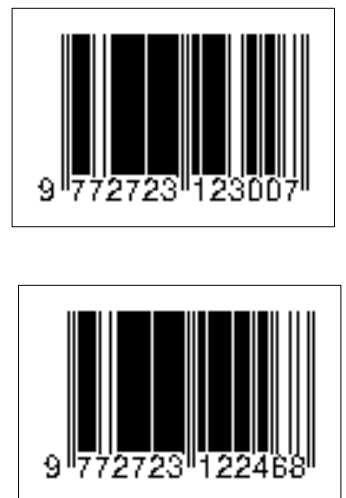

Editorial Office:

GUYUB: Journal of Community Engagement

Lembaga Penerbitan, Penelitian, dan Pengabdian kepada Masyarakat (LP3M) Universitas Nurul Jadid, Probolinggo, Jawa Timur, Indonesia 67291. Phone: 088830 77077, Hp: 082318007953

Email: jurnal.guyub@gmail.com

Website: https://ejournal.unuja.ac.id/index.php/guyub/index 